\title{
RANCANG BANGUN APLIKASI LAYANAN PERAWATAN DAN PENITIPAN HEWAN BERBASIS SMS GATEWAY PADA TOKO PETSHOP "PETZONE"
}

\author{
Rizky Adiputra $^{1)}$, Kodrat Iman Satoto ${ }^{2)}$, Rinta Kridalukmana ${ }^{2)}$ \\ Jurusan Teknik Sistem Komputer, Fakultas Teknik, Universitas Diponegoro, \\ Jln. Prof. Sudharto, Tembalang, Semarang, Indonesia \\ email : rizkyadiputra28@gmail.com
}

\begin{abstract}
Abstrak
Teknologi informasi merupakan sebuah kebutuhan manusia yang sangat penting, karena kemajuan zaman segala aktivitas kerja sebagian besar dibantu oleh teknologi informasi. Toko PetZone merupakan salah satu jenis usaha Petshop yang melayani penitipan dan perawatan hewan. Proses bisnis yang dilakukan Toko PetZone masih dilakukan dengan manual seperti contoh pencatatan data-data pelanggan maka kemajuan bisnis yang terjadi menyebabkan timbulnya kebutuhan sistem informasi yang dapat melakukan pencatatan layanan Pethotel, Pethospital, Jadwal kontrol hewan, Petgrooming dan monitoring keadaan hewan. Pengembangan sistem informasi lainnya ialah selain dapat melakukan pencatatan dapat memberikan informasi keadaan atau status hewan yang dititipkan melalui pesan singkat (SMS Gateway) sebagai alternatif baru untuk meningkatkan kepercayaan pelangan kepada Toko PetZone. Maka dari itu penelitian pembangunan aplikasi ini dibuat.
\end{abstract}

Tahapan dalam pembuatan aplikasi ini menggunakan beberapa tahap yaitu studi pustaka, observasi dan bimbingan. Metode yang digunakan dalam perancangan ialah metode waterfall. Metode ini sangat tepat dalam pembuatan aplikasi seperti ini, karena mempunyai alur yang memungkinkan perancangan untuk mengevaluasi aplikasi tanpa harus mengubah dari dasar. Aplikasi sistem penitipan dan perawatan hewan dibangun dengan menggunakan bahasa pemograman Java dan mesin database yang digunakan untuk menyimpan data-data menggunakan MySql Server. Antarmuka aplikasi sistem dibuat dengan GUI Interface yang memanfaatkan librari Java yaitu Java swing.

Hasil akhir dari penelitian ialah sebuah aplikasi dekstop yang dapat mencatat layananlayanan yang diberikan Toko PetZone dan meningkatkan kinerja Toko Petzone dan selain itu memberikan alternatif baru untuk meningkatkan kepercayaan pelanggan terhadap Toko Petzone melalui fasilitas monitoring hewan titipan dengan menggunakan pesan singkat (SMS Gateway).

.Kata Kunci : Teknologi Informasi, Java, MySql, SMS Gateway

\section{PENDAHULUAN}

\subsection{Latar Belakang}

Toko PetShop ( PetZone ) adalah suatu wirausaha yang bergerak pada bidang layanan terhadap hewan khususnya hewan peliharaan, berlokasi di area semarang.

Seiring berjalannya waktu, usaha PetShop atau layanan terhadap hewan peliharaan mulai dipandang sebagai jenis usaha yang menjanjikan. Oleh karena itu banyak toko - toko sejenis seperti ini mulai bermunculan dimana mana dengan berbagai macam fasilitas yang berbeda - beda dalam memenuhi kebutuhan customer. Untuk memenangkan pemilihan toko PetShop (PetZone) oleh customer dari kompetitor
- kompetiror, maka harus ada sebuah alternatif baru dalam memberikan layanan.

Salah satu cara alternatif baru tersebut ialah memanfaatkan perkembangan teknologi informasi dalam meningkatkan layanan. Teknologi informasi ini berupa pengembangan perangkat lunak dan perangkat keras yang dipadukan. Alternatif baru yang di tunjukan dalam penelitian ini, menghasilkan teknologi informasi berupa aplikasi komputer untuk menyampaikan sebuah status atau keadaan hewan saat dalam pelayanan secara otomatis dari pelayanan toko 
PetZone berupa pesan singkat kepada customer. Salain itu pada toko PetZone belum adanya pencatatan dan pembaruan status data - data hewan yang sedang dilayanin dalam bentuk komputerisasi semua masih manual, maka penelitian ini sangat bermanfaat bagi toko Petzone karena dapat dikerjakan dengan cepat, akurat, dan mudah bagi pengguna (staf jaga).

\subsection{Tujuan}

Tujuan dari tugas akhir ini adalah sebuah perangkat lunak sistem informasi layanan perawatan dan penitipan hewan yang dapat memberikan layanan pesan singkat yang berisi status atau keadaan hewan saat dalam pelayanan dan memberikan alternatif baru untuk Toko PetZone.

\subsection{Batasan Masalah}

Menghindari pembahasan yang meluas maka dalam tugas akhir ini di tetapkan batasan - batasan masalah, antaranya:

a. Pembuatan Aplikasi layanan perawatan dan penitipan hewan berbasis sms gateway ini menggunakan bahasa pemograman Java, dan basis data yang digunakan adalah MySQL.

b. Layanan SMS Gateway dalam sistem hanya sebatas media pemberi informasi status hewan saat dalam pelayanan.

c. Sistem ini digunakan untuk melakukan pencatatan dan pembaruan data status terhadap hewan - hewan saat dalam pelayanan di Toko PetShop (PetZone).

\section{TUNJAUAN PUSTAKA}

\subsection{Short Message Service (SMS)}

Short Message Service (SMS) (Talukder, 2005.) merupakan sebuah layanan yang banyak diaplikasikan pada sistem komunikasi tanpa kabel, memungkinkan dilakukannya pengiriman pesan dalam bentuk teks. SMS didukung oleh GSM (Global
System For Mobile Communication), TDMA (Time Division Multiple Access), CDMA (Code Division Multiple Access) yang berbasis pada telepon seluler yang saat ini banyak digunakan. SMS (Short Message Service) adalah merupakan salah satu layanan pesan teks yang dikembangkan dan distandarisasi oleh suatu badan yang bernama ETSI (European Telecommunication Standards Institute) sebagian dari pengembangan GSM (Global System for Mobile Communication) Phase 2, yang terdapat pada dokumentasi GSM 03.40 dan GSM 03.38. Fitur SMS ini memungkinkan perangkat Stasiun Seluler Digital (Digital Cellular Terminal, seperti Ponsel) untuk dapat mengirim dan menerima pesan-pesan teks dengan panjang sampai dengan 160 karakter melalui jaringan GSM. ${ }^{[12]}$

\subsection{Layanan Aplikasi SMS Gateway \\ SMS Gateway menerima} pesan SMS dari handphone melalui SMS Center (SMSC) operator selular. Pesan SMS tersebut diteruskan oleh gateway menjadi input bagi aplikasi untuk mengakses content atau database server. Setelah data ditangkap di dalam aplikasi, dapat dilakukan berbagai hal seperti pada proses pengolahan data pada umumnya. Misalnya merekam pesan SMS tersebut atau menggunakan pesan SMS tersebut sebagai keyword untuk melakukan query ke database. Fungsi dari sebuah SMS Gateway secara sederhana dapat digambarkan sebagai berikut ${ }^{[7]}$ :

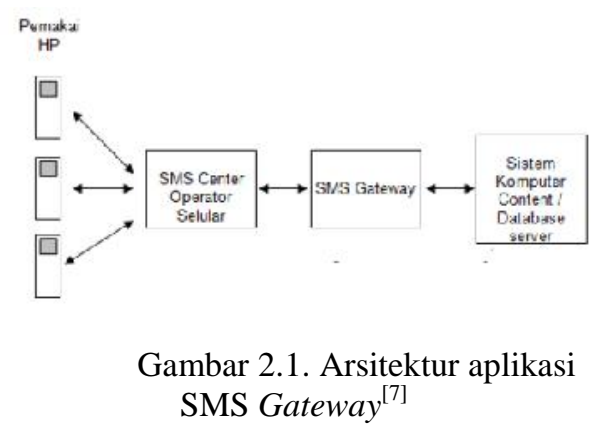




\subsection{Konsep Dasar Pemograman Berorientasi Objek}

Ada banyak cara untuk mengabstraksikan dan memodelkan objek-objek, mulai dan abstraksi objek, kelas, hubungan antar kelas sampai abstraksi sistem. Saat mengabstraksikan dan memodelkan objek, data dan prosesproses yang dipunyai oleh objek akan dienkapsilasi (dibungkus) menjadi satu kesatuan. ${ }^{[4]}$

\subsection{Pengembangan Sistem Informasi dengan Metode Waterfall}

Model waterfall adalah paradigma rekayasa perangkat lunak yang paling luas dipakai dan paling tua. Model waterfall mengusulkan sebuah pendekatan kepada perkembangan perangkat lunak yang sistematik dan sekuensial yang mulai pada tingkat dan kemajuan sistem pada seluruh analisis, desain, kode, pengujian dan pemeliharaan. Setelah setiap tahap didefinisikan, tahap tersebut 'diakhiri' (signed off) dan pengembangan berlanjut ke tahap berikutnya.

\subsection{Pemodelan Perancangan dengan DFD}

Penggunaan DFD Sebagai Modeling Tool dipopulerkan Oleh Demarco \& Yourdon (1979) dan Gane \& Sarson (1979) dengan menggunakan pendekatan Metoda Analisis Sistem Terstruktur. DFD (Data Flow Diagram) merupakan diagram yang digunakan untuk menggambarkan proses-proses yang terjadi pada sistem yang akan dikembangkan. Dengan model ini, datadata yang terlibat pada masing-masing proses dapat diidentifikasi. ${ }^{[9]}$

\subsection{Pemodelan Data Entity Relationship Diagram (ERD) \\ ERD ialah Entity Relationship} Diagram (ERD) adalah gambar atau diagram yang menunjukkan informasi dibuat, disimpan, dan digunakan dalam sistem bisnis. Entitas biasanya menggambarkan jenis informasi yang sama. Dalam entitas digunakan untuk menghubungkan antar entitas yang sekaligus menunjukkan hubungan antar data. ${ }^{[18]}$

\subsection{Bahasa Pemograman Java}

Java adalah bahasa pemograman orientasi objek yang berukuran kecil sederhana, aman , diinterpretasi atau dioptimasi secara dinamis, ber-bytecode, netral arsitektur, mempunyai garbagecollector, multithreading, mempunyai mekanisme penanganan kekecuali ( exception handing ), berbasi tipe untuk penulisan program mudah diperluas secara dinamis serta telah diperuntukkan sistem tersebar. ${ }^{[2]}$

\section{PERANCANGAN SISTEM}

Tahap perancangan sistem yang menggunakan metode Waterfall. Bab ini terdapat pula tiga dari tahapan awal metode Waterfall yaitu analisis kebutuhan, analisa, dan rancangan.

\subsection{Analisis Kebutuhan}

Toko Petshop ( PetZone ) merupakan sebuah usaha yang menyediakan layanan perawatan dan penitipan hewan. Proses bisnis yang terdapat dalam Toko PetZone ialah Pethotel, Pethospital, Petgrooming, Dokter hewan (Kontrol Hewan), fasilitas antar jemput hewan, penjualan aksesoris dan makanan hewan.

Berdasarkan latar belakang penelitian yang bertujuan untuk memberikan alternatif terhadap Toko PetZone maka diperlukan sebuah aplikasi sistem yang dapat memberikan informasi layanan (Monitoring) hewan pemilik berupa pesan singkat dari Toko PetZone ke costumer (pemilik hewan) yang sebelumnya belum ada sistem tersebut di Toko PetZone dan alternatif yang difokuskan pada fasilitas Pethotel, Pethospital, Petgrooming, Monitoring dan jadwal kontrol hewan. Setelah melakukan wawancara dan pengamatan secara 
langsung dengan pihak terkait terhadap keadaan di Toko PetZone, maka dapat di ketahui proses kerja yang ada di Toko PetZone saat ini dibagi menjadi beberapa proses :

Tabel 3.1. Kesimpulan Tahap Pelayanan

\begin{tabular}{|c|c|c|}
\hline Proses & Informasi & Kendala \\
\hline $\begin{array}{l}\text { 1. Layanan } \\
\text { terhadap } \\
\text { Pethotel }\end{array}$ & $\begin{array}{l}\text { - Stok } \\
\text { kandang } \\
\text { - } \\
\text { Pencatatan } \\
\text { dan } \\
\text { Pencarian } \\
\text { data } \\
\text { Pethotel }\end{array}$ & $\begin{array}{l}\text { - Proses cek } \\
\text { kandang yang } \\
\text { lambat } \\
\text { - Proses } \\
\text { pencarian } \\
\text { sulit dan data } \\
\text { dapat } \\
\text { tertukar-tukar } \\
\text { karena data } \\
\text { masih } \\
\text { dihimpun } \\
\text { manual }\end{array}$ \\
\hline $\begin{array}{l}\text { 2. Layanan } \\
\text { terhadap } \\
\text { Pethospital }\end{array}$ & $\begin{array}{l}\text { - Stok } \\
\text { kandang } \\
\text { - } \\
\text { Pencatatan } \\
\text { dan } \\
\text { Pencarian } \\
\text { data } \\
\text { Pethospital }\end{array}$ & $\begin{array}{l}\text { - Proses cek } \\
\text { kandang yang } \\
\text { lambat } \\
\text { - Proses } \\
\text { pencarian } \\
\text { sulit dan data } \\
\text { dapat } \\
\text { tertukar-tukar } \\
\text { karena data } \\
\text { masih } \\
\text { dihimpun } \\
\text { manual. } \\
\text { - lambat } \\
\text { dalam } \\
\text { mencari data } \\
\text { riwayat } \\
\text { hewan sakit. }\end{array}$ \\
\hline $\begin{array}{l}\text { 3. Layanan } \\
\text { terhadap } \\
\text { Petgroomi } \\
\text { ng }\end{array}$ & $\begin{array}{l}\text { - Data } \\
\text { Pribadi } \\
\text { Pembeli } \\
\text { - Data } \\
\text { Hewan dan } \\
\text { Fasilitas } \\
\text { grooming } \\
\text { yang } \\
\text { dipilih }\end{array}$ & $\begin{array}{l}- \text { Masih } \\
\text { manual } \\
\text { sehingga } \\
\text { lambat dan } \\
\text { kemungkinan } \\
\text { human error } \\
\text { yang tinggi } \\
\text { (data dapat } \\
\text { tertukar- } \\
\text { tukar) }\end{array}$ \\
\hline $\begin{array}{l}\text { 4. Layanan } \\
\text { terhadap } \\
\text { kontol dan } \\
\text { jadwal } \\
\text { kontrol }\end{array}$ & $\begin{array}{l}\text { - Data } \\
\text { hewan } \\
\text { kontrol } \\
\text { - Tanggal } \\
\text { kontrol }\end{array}$ & $\begin{array}{l}\text { Kemungkinan } \\
\text { pemilik dapat } \\
\text { lupa } \\
\text { membawa } \\
\text { hewannya } \\
\text { untuk kontrol } \\
\text { rutin atau } \\
\text { kontrol } \\
\text { lainnya }\end{array}$ \\
\hline
\end{tabular}

\begin{tabular}{|c|c|c|}
\hline $\begin{array}{l}5 . \\
\text { Monitoring } \\
\text { Hewan }\end{array}$ & $\begin{array}{l}\text { - Data } \\
\text { Monitoring }\end{array}$ & $\begin{array}{l}\text { - Pencatatan } \\
\text { masih manual } \\
\text { dapat } \\
\text { menimpulkan } \\
\text { kesalahan } \\
\text { dalam } \\
\text { memperbarui } \\
\text { data dengan } \\
\text { keadaan } \\
\text { aslinya jika } \\
\text { hewan yang } \\
\text { dititipkan } \\
\text { sedang } \\
\text { penuh. } \\
\text { - Pemilik } \\
\text { tidak tahu } \\
\text { keadaan } \\
\text { hewan yang } \\
\text { dititipkan }\end{array}$ \\
\hline
\end{tabular}

\subsubsection{Kebutuhan Pengguna}

Kebutuhan tersebut adalah manajemen data dan informasi pada layanan Toko PetZone khususnya Pethotel, Pethospital, Petgrooming, kontrol hewan, dan Monitoring yang mampu :

a. Mengelola data layanan Pethotel, Pethospital, Petgrooming, kontrol hewan, dan Monitoring.

b. Melakukan pencarian data layanan Pethotel, Pethospital, Petgrooming, kontrol hewan, dan Monitoring.

c. Melihat data layanan Pethotel, Pethospital, Petgrooming, kontrol hewan, dan Monitoring.

d. Melakukan peringatan atau pemberitahuan saat waktunya hewan kontrol kepada pemilik dengan pesan singkat.

e. Mengelola riwayat data layanan Pethotel, Pethospital, Petgrooming, kontrol hewan.

f. Memberikan informasi Monitoring status atau keadaan hewan pemilik kepada pemilik melalui pesan singkat.

g. Memberikan informasi status atau keadaan Petgrooming hewan pemilik kepada pemilik melalui pesan singkat.

h. Memberikan informasi jika pemilik hewan salah format sms. 
i. Melakukan keamanan data atau hak akses terhadap pengguna untuk melakukan pembaruan data-data layanan.

\subsection{Rancangan}

Tahapan ketiga dalam membangun sistem ialah tahap perancangan perangkat lunak yang merupakan proses multi langkah dan berfokus pada beberapa atribut perangkat lunak. Proses ini berdasarkan dari analisis sebelumnya sehingga menciptakan sebuah rancangan yang sesuai dengan kebutuhan dari pihak Toko PetZone.

1. Menentukan entitas yang terlibat dalam ERD

Tabel 3.2 Menentukan entitas

\begin{tabular}{|c|c|c|}
\hline Entitas & $\begin{array}{l}\text { Jenis } \\
\text { Entitas }\end{array}$ & Keterangan \\
\hline 1. Pegawai & $\begin{array}{c}\text { Entitas } \\
\text { Kuat }\end{array}$ & $\begin{array}{l}\text { Entitas yang } \\
\text { berisi data } \\
\text { pribadi } \\
\text { pegawai Toko } \\
\text { PetZone } \\
\text { disertai hak } \\
\text { akses dalam } \\
\text { sistem, } \\
\text { keberadaan } \\
\text { tidak } \\
\text { bergantung } \\
\text { pada entitas } \\
\text { lain. }\end{array}$ \\
\hline 2. Member & $\begin{array}{c}\text { Entitas } \\
\text { Kuat }\end{array}$ & $\begin{array}{l}\text { Entitas yang } \\
\text { berisi data } \\
\text { pemilik hewan } \\
\text { dan kategori } \\
\text { layanan yang } \\
\text { digunakan, } \\
\text { keberadaannya } \\
\text { tidak } \\
\text { bergantung } \\
\text { pada entitas } \\
\text { lain. }\end{array}$ \\
\hline 3. Pethotel & $\begin{array}{l}\text { Entitas } \\
\text { Lemah }\end{array}$ & $\begin{array}{l}\text { Entitas yang } \\
\text { berisi data } \\
\text { layanan hotel, } \\
\text { keberadaannya } \\
\text { bergantung } \\
\text { pada entitas } \\
\text { member. }\end{array}$ \\
\hline $\begin{array}{l}\text { 4. Pethospit } \\
\text { al }\end{array}$ & $\begin{array}{l}\text { Entitas } \\
\text { Lemah }\end{array}$ & $\begin{array}{ll}\text { Entitas } & \text { yang } \\
\text { berisi } & \text { data }\end{array}$ \\
\hline
\end{tabular}

\begin{tabular}{|c|c|c|}
\hline & & $\begin{array}{l}\text { layanan } \\
\text { hospital, } \\
\text { keberadaannya } \\
\text { bergantung } \\
\text { pada entitas } \\
\text { member. }\end{array}$ \\
\hline $\begin{array}{l}\text { 5. Petgroom } \\
\text { ing }\end{array}$ & $\begin{array}{l}\text { Entitas } \\
\text { Lemah }\end{array}$ & $\begin{array}{l}\text { Entitas yang } \\
\text { berisi data } \\
\text { layanan } \\
\text { grooming, } \\
\text { keberadaannya } \\
\text { bergantung } \\
\text { pada entitas } \\
\text { member. }\end{array}$ \\
\hline $\begin{array}{l}\text { 6. Kontrol } \\
\text { hewan }\end{array}$ & $\begin{array}{l}\text { Entitas } \\
\text { Lemah }\end{array}$ & $\begin{array}{l}\text { Entitas yang } \\
\text { berisi data } \\
\text { layanan } \\
\text { kontrol hewan, } \\
\text { keberadaannya } \\
\text { bergantung } \\
\text { pada entitas } \\
\text { member. }\end{array}$ \\
\hline $\begin{array}{l}\text { 7. Monitori } \\
n g\end{array}$ & $\begin{array}{l}\text { Entitas } \\
\text { Lemah }\end{array}$ & $\begin{array}{l}\text { Entitas yang } \\
\text { berisi data- } \\
\text { data hewan } \\
\text { yang } \\
\text { menginap, } \\
\text { keberadaannya } \\
\text { bergantung } \\
\text { pada entitas } \\
\text { Pethospital } \\
\text { dan Pethotel. }\end{array}$ \\
\hline
\end{tabular}

2. Menentukan relasi antar entitas

a. Relasi antara Member (Entitas Kuat) dengan Pethotel (Entitas Lemah)

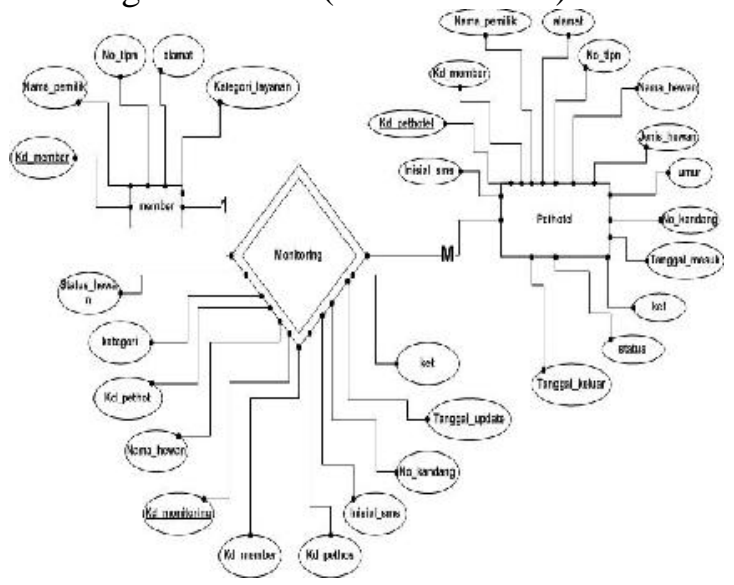

Gambar 3.1 Relasi antara member dengan

Pethotel

b. Relasi antara Member (Entitas Kuat) dengan Pethospital (Entitas Lemah) 


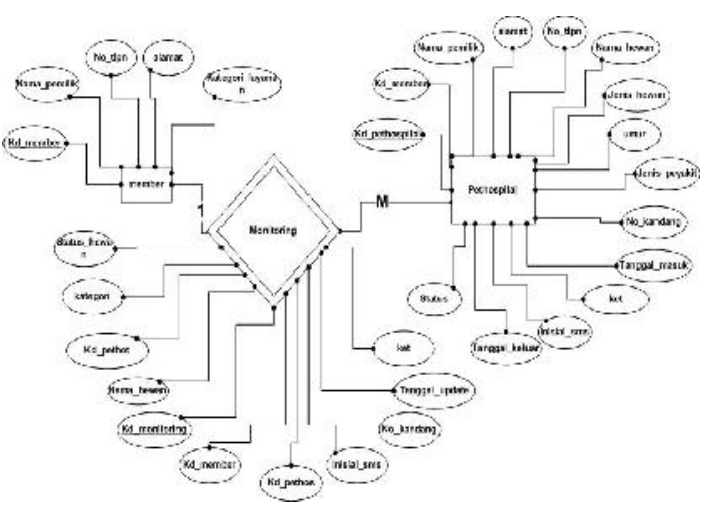

Gambar 3.2 Relasi antara member dengan Pethospital

c. Relasi antara Member (Entitas Kuat) dengan Petgrooming (Entitas Lemah)

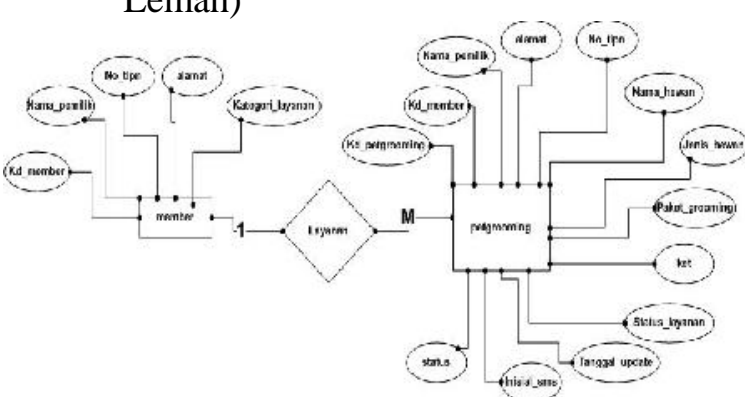

Gambar 3.3 Relasi antara member dengan Petgrooming

d. Relasi antara Member (Entitas Kuat) dengan kontrol hewan (Entitas Lemah)

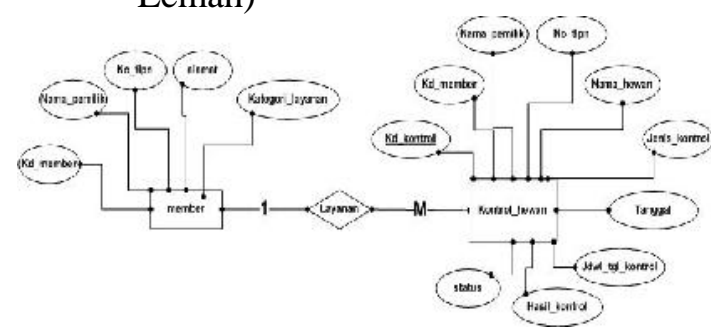

Gambar 3.4 Relasi antara member dengan kontrol hewan

Dekomposisi diagram merupakan kegiatan menguraikan sistem kedalam subsistem, proses, dan subproses komponen. Dekomposisi biasa digunakanan untuk menggambarkan dekomposisi sistem dalam bentuk bagan hirarki.

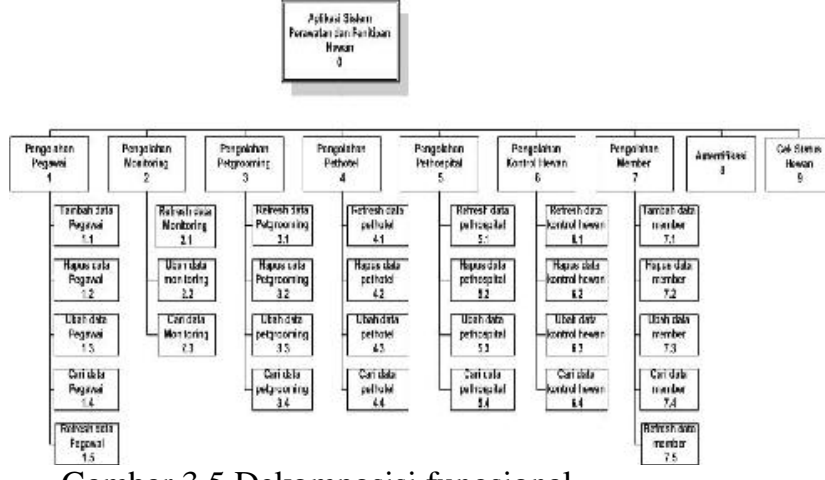

Gambar 3.5 Dekomposisi fungsional

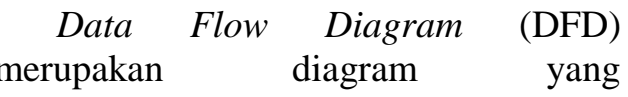
menggambarkan arus data pada sistem. DFD dapat digunakan untuk merepresentasikan sistem pada beberapa level abstraksi.

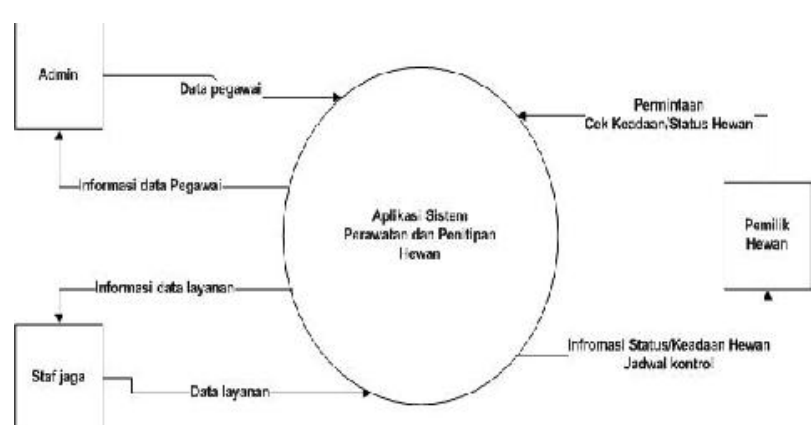

Gambar 3.6 DFD level 0 ( Diagram Konteks)

Gambar konteks diagram diatas dapat dilihat, menggambarkan proses yang terjadi dalam aplikasi Sistem Informasi Penitipan dan Perawatan Hewan. Pada sistem entitas yang telibat melibatkan tiga sumber atau tujuan data yaitu Admin, Staf jaga dan Pemilik Hewan.

\section{- Admin}

Bagian Admin dapat melakukan input, update, delete data pegawai dan juga sebagai pemberi hak akses kepada pengguna sistem. Lalu dapat melakukan Login dan Logout.

- Staf Jaga

Bagian Admin / Staf jaga dapat melakukan input, update, delete data data layanan yang terdapat pada sistem. Lalu dapat melakukan Login dan Logout. 
- Pemilik Hewan

Bagian Pemilik Hewan dalam sistem hanya dapat melakukan pengecekan keadaan atau status hewan dengan cara mengirim pesan singkatn menggunakan format tertentu.

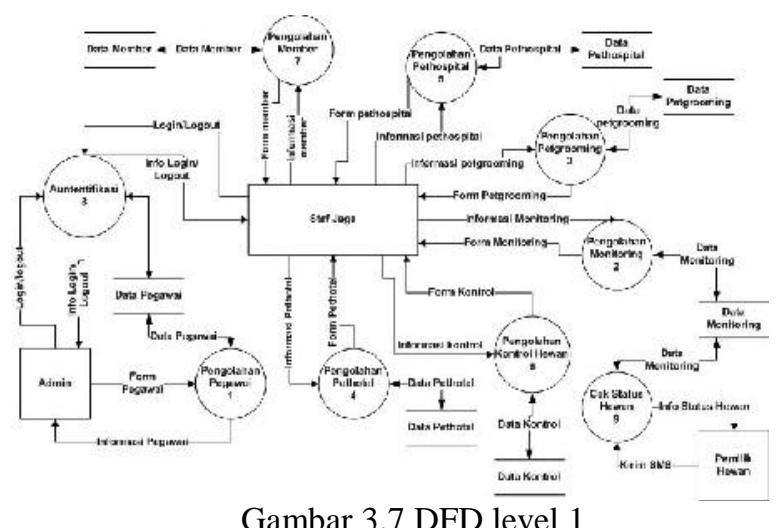

Diagram alir Fungsi Aplikasi

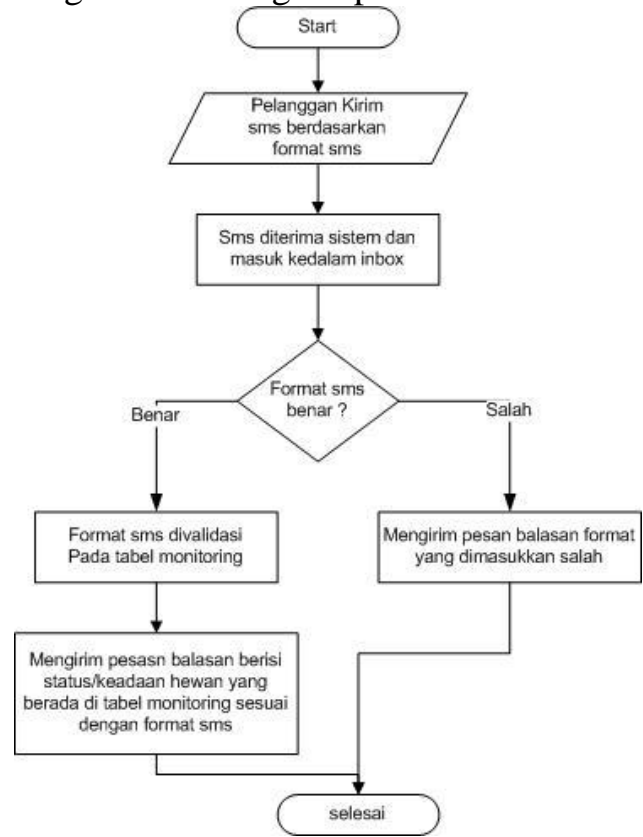

Gambar 3.8 Diagram alir monitoring status keadaan hewan dari pemilik ke sistem

Sesuai gambar diatas, proses dilakukan oleh pemilik hewan dengan mengirim sms dengan format yang telah diberikan petugas saat mendaftar Pethotel atau Pethospital. SMS diterima oleh sistem lalu masuk kedalam inbox, penyaringan terjadi apakah format benar atau salah. Jika salah maka pesan balasan yang akan diterima pelanggan yaitu pemberitahuan pesan salah, jika benar maka format sms divalidasi pada tabel monitoring dan mengirim pesan balasan yang akan diterima pelanggan berisi status atau keadaan hewan sesuai dengan format sms.

\section{IMPLEMENTASI DAN PENGUJIAN}

Tahap pengujian dilakukan dengan menggunakan metode black-box testing yang memfokuskan pada keperluan fungsional dari aplikasi. Karena itu uji coba black-box memungkinkan pengembang untuk menguji berupa cara pengguna menggunakan aplikasi.

Pengujian layanan cek status atau keadaan hewan saat dalam pelayanan oleh pelanggan.

Tabel 4.1 Pengujian layanan cek status atau keadaan hewan saat dalam pelayanan oleh pelanggan

\begin{tabular}{|c|c|c|c|}
\hline $\begin{array}{l}\text { Nama } \\
\text { Pengujian }\end{array}$ & $\begin{array}{l}\text { Bentuk } \\
\text { Pengujian }\end{array}$ & $\begin{array}{l}\text { Hasil yang } \\
\text { diharapkan }\end{array}$ & $\begin{array}{l}\text { Hasil } \\
\text { penguji } \\
\text { an }\end{array}$ \\
\hline $\begin{array}{l}\text { Pengujian } \\
\text { SMS layanan } \\
\text { Pethotel dan } \\
\text { Pethospital }\end{array}$ & $\begin{array}{l}\text { Mengirim } \\
\text { sms ke server } \\
\text { dengan } \\
\text { format } \\
\text { "STATUS\#IN } \\
\text { ISIAL SMS" }\end{array}$ & $\begin{array}{l}\text { SMS Balasan } \\
\text { keadaan status } \\
\text { hewan sesuai } \\
\text { dengan } \\
\text { keadaan yang } \\
\text { ada pada tabel } \\
\text { monitoring }\end{array}$ & Berhasil \\
\hline $\begin{array}{l}\text { Pegujian } \\
\text { SMS layanan } \\
\text { Petgrooming }\end{array}$ & $\begin{array}{l}\text { Mengirim } \\
\text { sms ke server } \\
\text { dengan } \\
\text { format } \\
\text { "GROOMIN } \\
\text { G\#INISIAL } \\
\text { SMS" }\end{array}$ & $\begin{array}{l}\text { SMS Balasan } \\
\text { keadaan status } \\
\text { layanan } \\
\text { petgrooming }\end{array}$ & Berhasil \\
\hline $\begin{array}{l}\text { Pengujian } \\
\text { Format sms } \\
\text { salah }\end{array}$ & $\begin{array}{l}\text { Mengirim } \\
\text { sms ke server } \\
\text { dengan } \\
\text { format yang } \\
\text { salah contoh } \\
\text { "Cek". }\end{array}$ & $\begin{array}{l}\text { SMS Balasan } \\
\text { pemberitahuan } \\
\text { bahwa format } \\
\text { salah. }\end{array}$ & Berhasil \\
\hline
\end{tabular}

\section{KESIMPULAN DAN SARAN \\ 4.1 Kesimpulan}

Hasil dari penelitian yang dimulai dari analisis hingga pengujian aplikasi sistem perawatan dan pemeliharaan hewan, maka dapat disimpulkan hal-hal sebagai berikut : 
1. Berdasarkan pengujian aplikasi disertai dengan ratusan proses pengujian dan sampel data dapat disimpulkan aplikasi berjalan dengan handal dan akuratn berdasarkan fungsinya.

2. Sistem yang dibangun merupakan aplikasi berbasis desktop yang dapat dijalankan langsung pada komputer dengan sistem operasi windows 7 yang sudah terinstal SDK (Software Development Kit) Java.

3. Inisial sms yang pelanggan (pemilik hewan) dapatkan saat mendaftarkan layanan hewannya, maka inisial sms itu yang akan berfungsi sebagai format sms yang hanya dimiliki oleh pelanggan itu sendiri dalam arti setiap pelanggan memiliki format sms yang berbeda-beda.

4. Sistem yang dibangun dikhususkan pada layanan Pethotel, Pethospital, Petgrooming, jadwal kontrol hewan yang merupakan pemantauan atau memonitoring dari setiap layanan tersebut, walaupun pada Toko Petshop (PetZone) terdapat layanan lainnya seperti antarjemput, booking dokter, penjualan hewan, makanan hewan dan aksesoris hewan.

\subsection{Saran}

$$
\text { Berdasarkan pengujian }
$$
terhadap aplikasi sistem perawatan dan pemeliharaan hewan yang telah dibuat, dapat diberikan beberapa saran sebagai berikut :.

1. Aplikasi sistem perawatan dan pemeliharaan hewan ini dapat dikembangkan lebih lanjut dalam fungsi memonitoring hewan, tidak hanya dengan sms yang berupa text namun bisa ditambahkan fitur gambar atau video yang keadaan hewan saat dilakukan proses updating.

2. Penelitian selanjutnya dapat dikembangkan lebih lanjut, sistem yang saat ini dibangun memonitoring hewan melalui sms, maka pengembanagn dapat dilakukan dengan merubah cara monitoring kedalam bentuk aplikasi smartphone yang dapat menampilkan status atau keadaan hewan dalam bentuk yang lebih menarik.

\section{DAFTAR PUSTAKA}

[1] Raharjo, Budi., Belajar Otodidak Membuat Database Menggunakan MySQL, Informatika. Bandung, 2011.

[2] Heryanto, Imam. Raharjo, Budi \& Haryono Arif., Mudah Belajar Java, Informatika, Bandung, 2009.

[3] Irawan., Java untuk Orang Awam, Maxikom, Palembang, 2011.

[4] Nugroho, Adi., Pemograman Berorientasi Objek, Informatika, Bandung, 2013.

[5] Kadir, Abdul., Algoritma \& Pemograman Menggunakan Java, Andi, Yogyakarta, 2012.

[6] Kadir, Abdul., Dasar Perancangan \& Implementasi Database Relasional, Andi, Yogyakarta, 2008

[7] Suryana, Tarana. 2012. SMS GATEWAY KANNEL SEBAGAI SARANA PENUNJANG INFORMASI AKADEMIK. Jurnal Ilmiah Komputer dan Informatika. Volume. I Nomor. 2 :

[8] Thoyib. 2010. PELAYANAN PELANGGAN BERBASIS SMS GATEWAY. Jurnal UMB. Volume I : 2-3.

[9] Budiani, Nunik., Data Flow Diagram sebagai alat bantu desai sistem, Jakarta, 2000.

[10] Kemal, Firman. Sistem Informasi Simpan Pinjam Di Koperasi Karyawan Pusat Perencanaan dan Pengembangan Perumka "DINAMIKO" PT. Kereta Api Indonesia (Persero), Bandung.

[11] Mustika. 2012. APLIKASI TRACKING PAKET BARANG EKSPEDISI PADA PT. BAHARI EKA NUSANTARA PALEMBANG. JURNAL 
TEKNOLOGI

DAN

INFORMATIKA. VOL.2NO.3 : 204.

[12] Wiharto, Yudi. 2011. Sistem Informasi Akademik Berbasis SMS Gateway. JURNAL TEKNOLOGI DAN INFORMATIKA. VOL.1NO.1 :23.

[13] AsokeK. Talukder, Mobile Computing, 2005.

[14] Cihar, Mical. Gammu Manual. Release 1.28.96. 2011.

[15] Universitas Surabaya. 2013. SMS Gateway Menggunakan Gammu Dan MySQL. http://www.ubaya.ac.id/2013/cont ent/articles_detail/33/SMSGateway-menggunakan-Gammudan-MySQL.html

[16] Hanifah, Raidah. 2010. Simulasi Sistem Informasi Geografis (SIG) Pemantauan Posisi Kendaraan Via SMS Gateway. Hal 2.

[17] Budi Sutedjo Dharma Utomo, S.Kom., MM., Perancangan dan Pembangungan Sistem Informasi,ANDI, Yogyakarta, 2002.

[18] Al Fatta,Hanif.2007. Analisis danPerancanganSistemInformasi. Yogyakarta: Andi.

[19] Edi, Dor. Betshani, Stevalin. 2009. Analisis Data dengan Menggunakan ERD dan Model Konseptual Data Warehouse. Jurnal Informatika, Vol.5.
BIOGRAFI PENULIS

\section{Rizky Adiputra (L2N009081)}

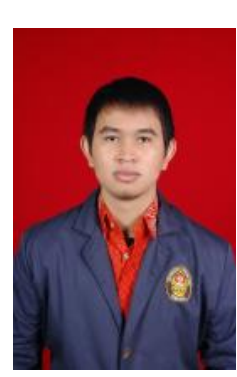

Lahir di Jakarta 28

Agustus

1991.

Memulai pendidikan di TK dan SD Kasih Asnanda, kemudian melanjutkan ke SMP Negeri 138 Jakarta, SMA Negeri 45

Jakarta. Saat ini penulis sedang menempuh pendidikan di Program Studi Sistem Komputer, Fakultas Teknik, Universitas Diponegoro, Semarang, angkatan 2009.

Menyetujui, Dosen Pembimbing I

Ir. Kodrat Iman Satoto, M.T. NIP. 196310281993031002

Dosen Pembimbing II

Rinta Kridalukmana, S.Kom., M.T. NIP. 197706152008011011 